\title{
Production and nutritional quality of black oat forage grown in different population stands under a successive cutting regime
}

[Produção e qualidade nutricional da forragem de aveia-preta cultivada em diferentes estandes populacionais sob regime de cortes sucessivos]

\section{A. Dochwat ${ }^{1}$, M. Neumann ${ }^{2}$, V.H. Bumbieris Junior ${ }^{3}$, J.C. Heker Junior ${ }^{2}$,} F.B. Cristo ${ }^{1}$, B.F. Zdepski ${ }^{1}$, A.M. Souza ${ }^{1}$, A.F. Matchula ${ }^{4}$

\author{
${ }^{1}$ Aluno de pós-graduação - Universidade Estadual do Centro-Oeste - Unicentro - Guarapuava, PR \\ ${ }^{2}$ Universidade Estadual do Centro-Oeste - Unicentro - Guarapuava, PR \\ ${ }^{3}$ Universidade Estadual de Londrina - UEL - Londrina, PR \\ ${ }^{4}$ Centro Universitário Campo Real - Campo Real - Guarapuava, PR
}

\begin{abstract}
The present study aimed to evaluate the agronomic productive and qualitative traits of forage of black oats grown in different stands of plants. The experimental design was a 2 × 2 factorial randomized complete block design consisting of four treatments, two plant stands (175 and 350 plants $\mathrm{m}^{2}$ ) associated with two successive cutting periods (vegetative and full vegetative) and four replications. The stand of plants did not influence the production of dry biomass; with 175 plants $\mathrm{m}^{2}$, we obtained a compensatory effect by the greater number of tillers $\mathrm{m}^{2-1}$ and/or tiller plant ${ }^{-1}$. The population stand influenced the chemical parameters, where 175 plants $\mathrm{m}^{2}$ resulted in forage with higher contents of hemicellulose and total digestible nutrients and a lower content of neutral detergent fiber. In the comparison between cuts, the first cut compared to the second presented higher values of crude protein $(26.53 \%)$. It is recommended that the black oat be cultivated with a population stand of 175 plants $\mathrm{m}^{2}$ for generating an increase in the number of tillers $\mathrm{m}^{2-1}$ and tillers plant ${ }^{-1}$, in addition to improving the in situ dry matter digestibility of the whole plant, without causing reduction of production of dry biomass per unit area.
\end{abstract}

Keywords: successive cuts, digestibility, winter forage, crude protein

\section{RESUMO}

O presente trabalho objetivou avaliar as características agronômicas produtivas e qualitativas da forragem da aveia-preta submetida ao cultivo com diferentes estandes populacionais. $O$ delineamento experimental foi de blocos ao acaso, em esquema fatorial $2 \times 2$, composto por quatro tratamentos, sendo dois estandes (175 e 350 plantas $\mathrm{m}^{2}$ ), associado a duas épocas de corte sucessivas (vegetativo e pleno vegetativo) e a quatro repetições. Os estandes populacionais não influenciaram a produção de biomassa seca, pois, com 175 plantas $m^{2}$, obteve-se efeito compensatório por maior número de perfilhos $m^{2-1}$ elou

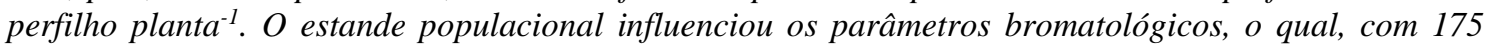
plantas $\mathrm{m}^{2}$, gerou produção de forragem com maiores teores de hemicelulose e de nutrientes digestíveis totais e um menor teor de fibra em detergente neutro. Na comparação entre os cortes, o primeiro corte, comparado ao segundo corte, apresentou maiores valores de proteína bruta (26,53\%). Recomenda-se a aveia-preta cultivada com estande populacional de 175 plantas $m^{2}$ por gerar aumento do número de perfilhos $m^{2-1}$ e perfilhos planta ${ }^{-1}$, além de melhorar a digestibilidade in situ da matéria seca da planta inteira, sem causar redução de produção de biomassa seca por unidade de área.

Palavras-chave: cortes sucessivos, digestibilidade, forragem hibernal, proteína bruta

Recebido para publicação em 2 de fevereiro de 2019

Aceito em 1 de outubro de 2019

E-mail: andrems_92@hotmail.com 


\section{INTRODUCTION}

Among the factors that may influence the growth of black oats, population stand or sowing density in the establishment of the crop stand out. The selection of the appropriate plant population for a given species influences the tillering capacity (Argenta et al., 2001), which may result in the compensation of existing voids in the crop. Tillering depends on the climatic conditions, management practices adopted (especially the plant population) and the cultivar used (Mundstock, 1999).

Grasses respond to population reduction by increasing the number of tillers per plant, as smaller populations decrease intra-specific competition and potentiate the quality of the light that reaches the plants (Almeida and Mundstock, 2001).

For Rosseto and Nakagawa (2001), black oats are characterized as a species with high tillering ability, and can grow up to 17 tillers per plant. Another alternative for the plant to compensate for smaller populations encompasses the increase in the dry biomass of tillers and the main stem. Research has shown that the production of dry biomass of black oats is higher in higher plant populations at the beginning of development, tending to disappear during the crop cycle, especially after a first cut (Flaresso et al., 2001).

Although the literature contains works related to the effect of sowing density on the growth of black oats, the behavior shown there may not be the same in other places or years (tillering depends on climatic conditions), or when black oats are used for direct grazing (Alves et al., 2004).

Thus, the aim of this study was to evaluate the agronomic productive and qualitative traits of the forage of black oats grown with different population stands associated with two cutting seasons.

\section{MATERIAL AND METHODS}

The experiment was carried out by the Animal Production Center (NUPRAN), along with the Master's Degree in Agronomy in the Plant Production area, belonging to the Agrarian and
Environmental Sciences sector of the Central Western Paraná State University (UNICENTRO), located in the municipality of Guarapuava, State of Paraná, located in the subtropical zone of Paraná, at the geographical coordinates $25^{\circ} 23^{\prime} 02^{\prime}$ " south latitude and $51^{\circ} 29^{\prime} 43^{\prime \prime}$ west longitude and $1.026 \mathrm{~m}$ altitude.

The climate of the region according to the Köppen classification is $\mathrm{Cfb}$ (humid, subtropical mesothermal), with mild summers and moderate winter, with no defined dry season and with severe frosts. The average annual rainfall is 1.944 $\mathrm{mm}$, minimum annual average temperature is $12.7^{\circ} \mathrm{C}$, maximum annual average temperature is $23.5^{\circ} \mathrm{C}$ and relative humidity of $77.9 \%$. Figure 1 illustrates the average rainfall in $\mathrm{mm}$, as well as the maximum and minimum temperature in ${ }^{\circ} \mathrm{C}$ during the experimental period.

The soil of the experimental area was classified as Latossolo Bruno Típico (Pott, 2007), and upon crop implementation, it showed the following chemical characteristics (0 to $20 \mathrm{~cm}$ profile): $\mathrm{pH}$ $\mathrm{CaCl}_{2}$ 0.01M: 4.7; P: $1.1 \mathrm{mg} \mathrm{dm}^{-3} ; \mathrm{K}^{+}: 0.2$ cmolc $\mathrm{dm}^{-3}$; OM: $2.62 \mathrm{~g} \mathrm{dm}^{-3} ; \mathrm{Al}^{3+}: 0.0$ cmolc dm${ }^{-3} ; \mathrm{H}^{+}$ $+\mathrm{Al}^{3+}: 5.2$ cmolc dm ${ }^{-3} ; \mathrm{Ca}^{2+}: 5.0$ cmolc $\mathrm{dm}^{-3}$; $\mathrm{Mg}^{2+}$ : $5.0 \mathrm{cmolc} \mathrm{dm}^{-3}$ and base saturation (V\%): $67.3 \%$.

The black oat cv. Embrapa 139 was sown under agricultural zoning for the region of Guarapuava, in a no-tillage system. The sowing was done with row spacing of 0.17 meters and average sowing depth of 2 centimeters. The experimental area consisted of $68 \mathrm{~m}^{2}$, distributed in 8 plots of $8.5 \mathrm{~m}^{2}$ each $(1.70 \mathrm{~m}$ x $5.00 \mathrm{~m})$, where each plot represented an experimental unit (repetition).

This was a 2 × 2 factorial randomized block design, consisting of four treatments, two plant stands (175 and 350 plants $\mathrm{m}^{2-1}$ ) associated with two successive cutting seasons (vegetative and full vegetative stages) and four repetitions. Upon sowing, $285 \mathrm{~kg} \mathrm{ha}^{-1}$ fertilizer 08-30-20 (N-P $\mathrm{O}_{5-}$ $\mathrm{K}_{2} \mathrm{O}$ ) was used, respecting recommendations of the Manual of Fertilization and Liming for the State of Paraná (Manual..., 2017). Nitrogen fertilization was carried out at once with $200 \mathrm{~kg} \mathrm{~N}$ $\mathrm{ha}^{-1}$, as urea at the full tillering phase of black oats. 


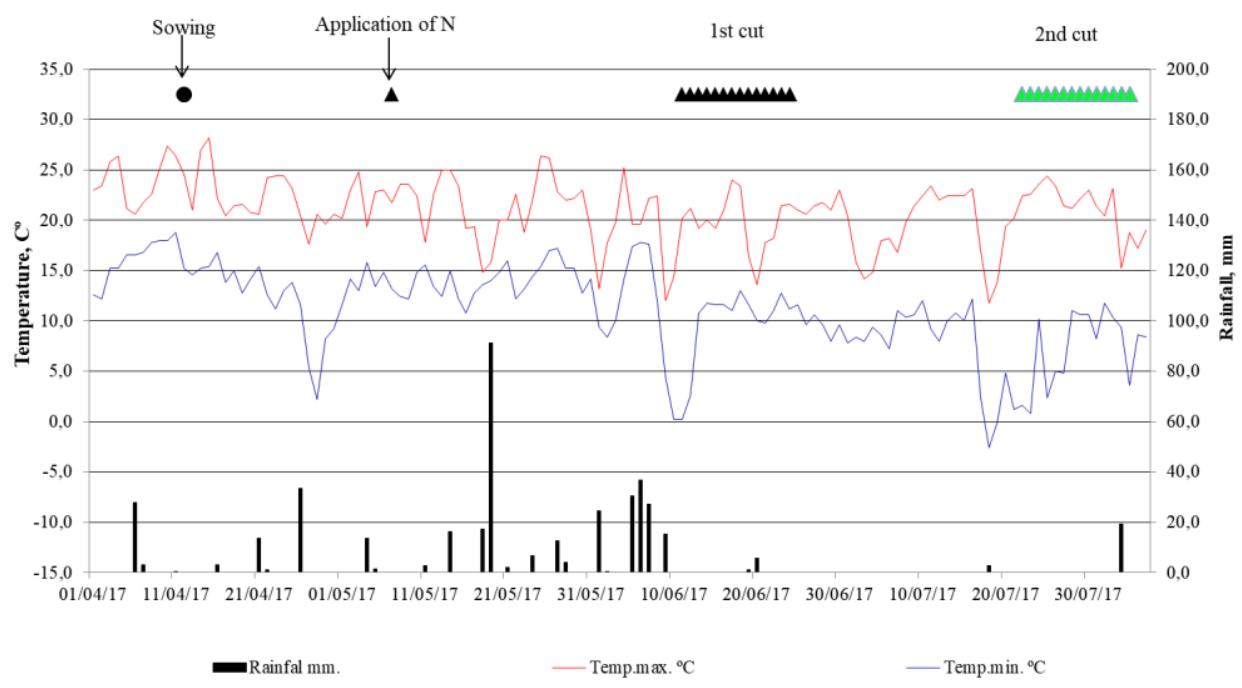

Source: Experimental station of SIMEPAR/UNICENTRO, Guarapuava, State of Paraná, 2017.

Figure 1. Rainfall averages $(\mathrm{mm})$, maximum and minimum temperature $\left({ }^{\circ} \mathrm{C}\right)$ during the growing season of the crop.

Weeds were chemically controlled using glyphosate-based herbicide (Roundup $\mathrm{WG}^{\circledR}$ commercial product: $\left.3.0 \mathrm{~kg} \mathrm{ha}{ }^{-1}\right)$ in the desiccation of the experimental area 15 days before sowing, and in the management of the crop 30 days after planting with the application of herbicide based on metsulfuron- methyl (Ally ${ }^{\circledR}$ commercial product: $\left.6.6 \mathrm{~g} \mathrm{ha}^{-1}\right)$.

The real population was determined 15 days after the emergence of the plants by counting the number of plants per linear meter per plot. Sequentially, 35 days after emergence, the tiller count per linear meter was used to estimate the number of tillers plant ${ }^{-1}$.

In the crop management, for the evaluation of the productive and qualitative traits of the forage, two sequential cuts were made, when the light interception reached an average of 90 to $95 \%$ in the plot. Light interception (LI), which is estimated by photosynthetically active radiation (PAR), was measured by the AccuPAR LP-80 digital linear ceptometer (Decagon, Devices). In this context, the first cut was performed on average at 59 days after plant emergence (DAP) and the second cut at 107 DAP.

The cut of the plants, contained in the useful area of each plot $\left(6.8 \mathrm{~m}^{2}\right)$, was carried out manually at $10 \mathrm{~cm}$ from the ground. The relationship between the weight of the harvested material and the area unit allowed to estimate the fresh biomass production $\left(\mathrm{kg} \mathrm{ha}^{-1}\right)$. A $1 \mathrm{~kg}$ sample of each freshly harvested material was sent to the laboratory for the physical composition analysis by separation of the forage structural components and dehydrated in a forced air oven set at $55^{\circ} \mathrm{C}$ to constant weight. The adoption of this practice allowed for the determination of the percentage composition of the anatomical structures of the plant as stem, green leaves and senescent leaves.

Immediately after harvesting, a second homogeneous sample of $500 \mathrm{~g}$ of each plot was also collected to determine the dry matter content by means of forced air drying at $55^{\circ} \mathrm{C}$ to constant weight. The relationship between fresh biomass yield and dry matter content of the plants allowed to estimate the total dry biomass production $\left(\mathrm{kg} \mathrm{ha}^{-1}\right)$.

The pre-dried samples of the original material were ground in a Wiley mill with a $1 \mathrm{~mm}$ sieve, where the total dry matter was determined in an oven at $105^{\circ} \mathrm{C}$ for 4 hours, crude protein (CP) by the micro Kjedahl method and mineral matter (MM) by incineration at $550^{\circ} \mathrm{C}$ for 4 hours according to techniques described in AOAC (Official..., 1995). The contents of neutral detergent fiber (NDF), acid detergent fiber (ADF) and lignin (LIG) were determined according to Silva and Queiroz (2009). From these values, hemicellulose (HEM) content was estimated by 
difference between NDF and ADF and cellulose (CEL) content, by difference between NDF and LIG. The total digestible nutrient content (TDN, $\%$ ) was obtained via equation [TDN, $\%=87.84$ (0.70 x ADF)], suggested by Bolsen et al. (1996).

Dry matter digestibility of forage and the components stem, green leaves and senescent leaves was estimated by in situ technique using nylon bags measuring $12 \mathrm{~cm} \mathrm{x} 8 \mathrm{~cm}$ and with pores of 40 to $60 \mu \mathrm{m}$ containing $5 \mathrm{~g}$ dry sample of each material, ground to $1 \mathrm{~mm}$, for later incubation in the rumen (Nocek, 1988). The incubation times used for forage were 1, 6, 12, 24, 36 and 48 hours and for the stem, and 48 hours for green and senescent leaves. For this, two steers with 24 months of age, average body weight of $650 \mathrm{~kg}$, and rumen fistula were used.

Data were tested by analysis of variance (ANOVA) and then, when the difference was detected, the F-test was used to compare the means at 5\% significance, using the SAS (version
6.4) software. Data on the ruminal disappearance rate of dry matter were used in regression analysis (proc reg) of the statistical software SAS (version 6.4).

\section{RESULTS AND DISCUSSION}

Table 1 lists the mean number of plants $\mathrm{m}^{2-1}$, of tillers $\mathrm{m}^{2-1}$, number of tillers plant ${ }^{-1}$ and dry biomass production of black oats cultivated with two plant population densities associated with two cutting seasons.

In the overall mean, when black oats were cultivated with 175 plants $\mathrm{m}^{2}$, there was a pasture structure with a lower $(\mathrm{P}<0.05)$ plant population (158 vs 335 plants $\mathrm{m}^{2-1}$ ), which resulted in higher $(\mathrm{P}<0.05)$ tillering $\left(617\right.$ vs $527 \mathrm{~m}^{2-1}$ and/or 3.8 tillers versus 1.5 tillers plant $\left.{ }^{-1}\right)$ causing no reduction $(\mathrm{P}>0.05)$ in cumulative biomass production (4.693 vs $4.776 \mathrm{~kg} \mathrm{ha}^{-1}$ ), compared to the crop with stand of 350 plants $\mathrm{m}^{2}$.

Table 1. Mean values of number of plants $\mathrm{m}^{2-1}$, tillers $\mathrm{m}^{2-1}$, number of tillers plant ${ }^{-1}$ and dry biomass production of black oats grown with two population stands associated with two cutting seasons

\begin{tabular}{|c|c|c|c|}
\hline \multirow{2}{*}{$\begin{array}{l}\text { Stand of plants } \\
\mathrm{m}^{2}\end{array}$} & \multicolumn{2}{|c|}{ Cuts } & \multirow[t]{2}{*}{ Mean/Total } \\
\hline & $1^{\text {st }}$ & $2^{\text {nd }}$ & \\
\hline & \multicolumn{3}{|c|}{ Plants $\mathrm{m}^{2-1}$} \\
\hline 175 & 171 & 145 & $158 \mathrm{~B}$ \\
\hline 350 & 350 & 321 & $335 \mathrm{~A}$ \\
\hline Mean & $260 \mathrm{a}$ & $233 \mathrm{~b}$ & \\
\hline \multicolumn{4}{|c|}{ Tillers $\mathrm{m}^{2-1}$} \\
\hline 175 & 630 & 605 & $617 \mathrm{~A}$ \\
\hline 350 & 568 & 487 & $527 \mathrm{~B}$ \\
\hline Mean & $599 a$ & $546 \mathrm{a}$ & \\
\hline \multicolumn{4}{|c|}{ Tillers plant ${ }^{-1}$} \\
\hline 175 & 3.6 & 4.1 & $3.8 \mathrm{~A}$ \\
\hline 350 & 1.6 & 1.5 & $1.5 \mathrm{~B}$ \\
\hline Mean & $2.6 \mathrm{~b}$ & $2.8 \mathrm{a}$ & \\
\hline \multicolumn{4}{|c|}{ Dry biomass production, $\mathrm{kg} \mathrm{ha}^{-1}$} \\
\hline 175 & 1,827 & 2,866 & $4,693 \mathrm{~A}$ \\
\hline 350 & 2,146 & 2,629 & $4,776 \mathrm{~A}$ \\
\hline Mean & $1,827 \mathrm{~b}$ & $2,866 \mathrm{a}$ & \\
\hline
\end{tabular}

Mean values followed by different uppercase letters in the same column in the black aot comparison between plant stands or followed by different lowercase letters in the same row in the comparison between cutting seasons are significantly different from each other by the F-test at $5 \%$ probability.

*First cut (1st); Second cut (2nd)

Data in Table 1 also show that the effect of successive cuts in the management of black oat forage, independent of the population stand, promotes reduction $(\mathrm{P}<0.05)$ in the plant population (from 260 to 233 plants $\mathrm{m}^{2-1}$ ) but increases tillering capacity (from 2.6 to 2.8 tillers plant $^{-1}$ ) and also increases dry biomass production $\left(1.827\right.$ vs $\left.2.866 \mathrm{~kg} \mathrm{ha}^{-1}\right)$ from the first cut to the second. 
Martins et al. (2008) when working with black oats in the population densities of 130 and 420 plants $\mathrm{m}^{2}$, observed significant reductions in the participation of tillers with the increase of the population density, as well as the tillering capacity per plant (4.1 to 2.0 tillers plant ${ }^{-1}$ ).

In studies conducted with black oats, Flaresso et al. (2001) used sowing densities of 260, 350 and 450 plants $\mathrm{m}^{2}$ and obtained average values of dry biomass production of $2.077,2.226$ and $2.428 \mathrm{~kg}$ $\mathrm{ha}^{-1}$, respectively, lower than those of the present study.
Orterro et al. (2013) evaluated the density of 220, 350 and 450 plants $\mathrm{m}^{2}$ of black oats and reported yield of $4.125,4.258$ and $4.260 \mathrm{~kg}$ dry biomass ha1 . These results are in agreement with the present study as they found no influence of the stand of plants for the production of dry biomass.

In Table 2 it is possible to observe that the stand of plants $\mathrm{m}^{2}$, in black oats, did not influence $(\mathrm{P}<0.05)$ the contents of dry matter of the whole plant, its green leaves, stems and senescent leaves components, regardless of the cutting season.

Table 2. Dry matter content of whole plant, green leaves, stems and senescent leaves of black oats grown with two population stands associated with two cutting seasons

\begin{tabular}{|c|c|c|c|}
\hline \multirow{2}{*}{$\begin{array}{l}\text { Stand of plants } \\
\mathrm{m}^{2}\end{array}$} & \multicolumn{2}{|c|}{ Cuts } & \multirow[t]{2}{*}{ Mean } \\
\hline & $1 \mathrm{st}$ & 2nd & \\
\hline & \multicolumn{3}{|c|}{ Whole plant, \% } \\
\hline 175 & 13.06 & 23.85 & $18.46 \mathrm{~A}$ \\
\hline 350 & 12.76 & 24.08 & $18.42 \mathrm{~A}$ \\
\hline Mean & $12.91 \mathrm{~b}$ & $23.97 \mathrm{a}$ & \\
\hline \multicolumn{4}{|c|}{ Green leaves, $\%$} \\
\hline 175 & 13.84 & 42.46 & $28.15 \mathrm{~A}$ \\
\hline 350 & 13.13 & 40.20 & $26.66 \mathrm{~A}$ \\
\hline Mean & $13.49 \mathrm{~b}$ & $41.33 \mathrm{a}$ & \\
\hline \multicolumn{4}{|c|}{ Stem, $\%$} \\
\hline 175 & 8.60 & 19.40 & $14.00 \mathrm{~A}$ \\
\hline 350 & 7.99 & 19.00 & $13.50 \mathrm{~A}$ \\
\hline Mean & $8.30 \mathrm{~b}$ & $19.20 \mathrm{a}$ & \\
\hline \multicolumn{4}{|c|}{ Senescent leaves, $\%$} \\
\hline 175 & - & 32.87 & $32.87 \mathrm{~A}$ \\
\hline 350 & - & 30.48 & $30.48 \mathrm{~A}$ \\
\hline Mean & - & 31.68 & \\
\hline
\end{tabular}

Mean values followed by different uppercase letters in the same column in the black aot comparison between plant stands or followed by different lowercase letters in the same row in the comparison between cutting seasons are significantly different from each other by the F-test at $5 \%$ probability.

*First cut (1st); Second cut (2nd)

On the dry matter content between the cuts (Table 2) it is possible to observe that these increased $(\mathrm{P}<0.05)$ from the first to the second cut. The dry matter content of the whole plant obtained in the first cut increased from $12.91 \%$ to $23.97 \%$ in the second cut, behavior also observed for dry matter content of the green leaves (from 13.49 to $41.33 \%$ ) and of stems (from 8.30 to $19.20 \%$ ), respectively.

In evaluating winter cereals under cutting Meinerz et al. (2011) obtained increase in dry matter content of the plant and its components in the second cut; a behavior that resembles that of the present study and is a fact that can be attributed to the advancement of the plant phenological stage, as it is known that the water content of plant cells decreases when older.

Data of the physical composition of the black oat plant grown in different population stands subjected to successive cuts are listed in Table 3, where the increase in the number of plants from 175 to 350 plants $\mathrm{m}^{2}$ did not cause change in the structure of the forage produced, regardless of the cutting season. 
Table 3. Participation of green leaves, stems and senescent leaves in the physical composition of the plant and leaf/stem ratio of black oats grown with two population stands associated with two cutting seasons

\begin{tabular}{|c|c|c|c|}
\hline \multirow{2}{*}{$\begin{array}{l}\text { Stand of plants } \\
\mathrm{m}^{2}\end{array}$} & \multicolumn{2}{|c|}{ Cuts } & \multirow[t]{2}{*}{ Mean } \\
\hline & $1 \mathrm{st}$ & 2 nd & \\
\hline & \multicolumn{3}{|c|}{ Green leaves, \% DM } \\
\hline 175 & 62.82 & 29.97 & $46.39 \mathrm{~A}$ \\
\hline 350 & 62.78 & 36.35 & $49.57 \mathrm{~A}$ \\
\hline Mean & $62.80 \mathrm{a}$ & $33.16 \mathrm{~b}$ & \\
\hline \multicolumn{4}{|c|}{ Stem, \% DM } \\
\hline 175 & 37.18 & 51.32 & $44.25 \mathrm{~A}$ \\
\hline 350 & 37.22 & 51.14 & $44.18 \mathrm{~A}$ \\
\hline Mean & $37.20 \mathrm{~b}$ & $51.23 \mathrm{a}$ & \\
\hline \multicolumn{4}{|c|}{ Senescent leaves, \% DM } \\
\hline 175 & - & 6.12 & $6.12 \mathrm{~A}$ \\
\hline 350 & - & 4.05 & $4.05 \mathrm{~A}$ \\
\hline Mean & & 5.09 & \\
\hline \multicolumn{4}{|c|}{ Leaf/stem ratio } \\
\hline 175 & 1.70 & 0.58 & $1.14 \mathrm{~A}$ \\
\hline 350 & 1.71 & 0.71 & $1.21 \mathrm{~A}$ \\
\hline Mean & $1.71 \mathrm{a}$ & $0.65 \mathrm{~b}$ & \\
\hline
\end{tabular}

Mean values followed by different uppercase letters in the same column in the black aot comparison between plant stands or followed by different lowercase letters in the same row in the comparison between cutting seasons are significantly different from each other by the F-test at $5 \%$ probability.

*First cut (1st); Second cut (2nd)

*Dry mater $(\mathrm{DM})$

In the comparison between the cuts, the first cut was the one with the highest participation of green leaves, with $62.80 \%$, differing from the second cut with $33.16 \%$, while the participation of stem showed opposite behavior, increasing $37.20 \%$ in the first cut to $51.23 \%$ in the second cut (Table 3 ). Still in the same table, for the leaf/stem parameter the first cut was higher than the second (1.71 against 0.65 ).

Martins et al. (2008), using different black oat densities reported linear reduction in leaf/stem ratio with increasing number of plants, a behavior that can be explained due to the lower elongation that occurs in black oats in lower population densities. In relation to the percentage of stem and leaves. Kremes et al. (2013) evaluated black oat genotypes at pre-flowering using density of 350 plants $\mathrm{m}^{2}$ and found values of $77.28 \%$ of leaves and $22.72 \%$ of stem.

Mundstock (1999) points out that the reduction in the leaf/stem ratio in the cuts after the first one is due to the tillering stimulation that tends to increase defoliation in the early stages and to reduce in the late stages of development of the plants.

Table 4 presents the digestibility data of the green leaves, stems and senescent leaves components. The plant population caused no $(\mathrm{P}>0.05)$ modifications in the in situ digestibility of any of the structural components of the plant, which is explained by the absence of variations in the dry matter content as shown in (Table 2) and in the physical structure of the plant (Table 3 ).

Still in Table 4 it is observed that the digestibility of the stem and green leaf components presented higher digestibility, $(63.76 \%$ vs $44.11 \%$ and $76.40 \%$ vs $56.93 \%$, respectively) in the first cut when compared to the second cut.

Results of leaf and stem digestibility close to the present study were reported by Orterro et al. (2013) when evaluating the black oats in different population densities. Pedroso et al. (2010) evaluated black oats in three successive cuts under grazing simulation and observed that the digestibility of the structural components and of the whole plant reduced with each cut. 
Table 4. In situ dry matter digestibility of forage structural components (48 hours of incubation) of black oats grown with two population stands associated with two cutting seasons

\begin{tabular}{|c|c|c|c|}
\hline \multirow{2}{*}{$\begin{array}{l}\text { Stand of plants } \\
\mathrm{m}^{2}\end{array}$} & \multicolumn{2}{|c|}{ Cuts } & \multirow[t]{2}{*}{ Mean } \\
\hline & $1 \mathrm{st}$ & 2 nd & \\
\hline \multicolumn{4}{|c|}{ Stems, \% } \\
\hline 175 & 63.24 & 45.08 & $54.16 \mathrm{~A}$ \\
\hline 350 & 64.28 & 43.15 & $53.71 \mathrm{~A}$ \\
\hline Mean & $63.76 \mathrm{a}$ & $44.11 \mathrm{~b}$ & \\
\hline \multicolumn{4}{|c|}{ Green leaves, \% } \\
\hline 175 & 81.01 & 56.31 & $68.66 \mathrm{~A}$ \\
\hline 350 & 71.78 & 57.54 & $64.66 \mathrm{~A}$ \\
\hline Mean & $76.40 \mathrm{a}$ & $56.93 \mathrm{~b}$ & \\
\hline \multicolumn{4}{|c|}{ Senescent leaves, $\%$} \\
\hline 175 & - & 60.51 & $60.51 \mathrm{~A}$ \\
\hline 350 & - & 63.40 & $63.40 \mathrm{~A}$ \\
\hline Mean & - & 61.96 & \\
\hline
\end{tabular}

Mean values followed by different uppercase letters in the same column in the black aot comparison between plant stands or followed by different lowercase letters in the same row in the comparison between cutting seasons are significantly different from each other by the F-test at $5 \%$ probability.

*First cut (1st); Second cut (2nd)

In the evaluation of the nutritional value of the forage (Table 5), it is observed that the population of plants only influenced the acid detergent fiber contents. Black oat when grown with 175 plants $\mathrm{m}^{2}$ had lower $(\mathrm{P}<0.05)$ acid detergent fiber content when compared to the density of 350 plants $\mathrm{m}^{2}$; according to Martins et al. (2008) larger populations promote greater elongation of the stem, and this component of the plant has high content of cell wall structural constituents, especially lignin.

Table 5. Contents of mineral matter, crude protein, neutral detergent fiber and acid detergent fiber of black oats grown with two population stands associated with two cutting seasons

\begin{tabular}{|c|c|c|c|}
\hline \multirow{2}{*}{$\begin{array}{l}\text { Stand of plants } \\
\mathrm{m}^{2}\end{array}$} & \multicolumn{2}{|c|}{ Cuts } & \multirow[t]{2}{*}{ Mean } \\
\hline & $1 \mathrm{st}$ & 2nd & \\
\hline & \multicolumn{3}{|c|}{ Mineral matter, \% DM } \\
\hline 175 & 8.98 & 5.24 & $7.11 \mathrm{~A}$ \\
\hline 350 & 9.24 & 5.50 & $7.37 \mathrm{~A}$ \\
\hline Mean & $9.11 \mathrm{a}$ & $5.37 \mathrm{~b}$ & \\
\hline \multicolumn{4}{|c|}{ Crude protein, \% DM } \\
\hline 175 & 26.75 & 18.49 & $22.62 \mathrm{~A}$ \\
\hline 350 & 26.30 & 18.68 & $22.49 \mathrm{~A}$ \\
\hline Mean & $26.53 \mathrm{a}$ & $18.59 \mathrm{~b}$ & \\
\hline \multicolumn{4}{|c|}{ Neutral detergent fiber, \% DM } \\
\hline 175 & 50.34 & 40.50 & $45.42 \mathrm{~A}$ \\
\hline 350 & 50.42 & 40.07 & $45.25 \mathrm{~A}$ \\
\hline Mean & $50.38 \mathrm{a}$ & $40.29 \mathrm{~b}$ & \\
\hline \multicolumn{4}{|c|}{ Acid detergent fiber, $\%$ DM } \\
\hline 175 & 26.29 & 31.94 & $29.12 \mathrm{~B}$ \\
\hline 350 & 32.33 & 31.33 & $31.83 \mathrm{~A}$ \\
\hline Mean & $29.31 \mathrm{~b}$ & $31.64 \mathrm{a}$ & \\
\hline
\end{tabular}

Mean values followed by different uppercase letters in the same column in the black aot comparison between plant stands or followed by different lowercase letters in the same row in the comparison between cutting seasons are significantly different from each other by the F-test at $5 \%$ probability.

*First cut (1st); Second cut (2nd)

*Dry mater (DM) 
In the comparison between the cuts, regardless of the plant stand, the crude protein contents were higher $(\mathrm{P}<0.05)$ in the first cut with $26.53 \%$ compared to the second with $18.59 \%$, the mineral content followed the same trend, in the first cut it was higher than in the second with $9.11 \%$ and $5.37 \%$ respectively. However, the neutral detergent fiber content of the first cut was $50.38 \%$, differing $(\mathrm{P}<0.05)$ from the second cut with $40.29 \%$, but the acid detergent fiber content was lower in the first cut in relation to the second (29.31\% against $31.64 \%$ ). This justifies the variations between first and second cuts found in the dry matter digestibilities of stem and green leaves (Table 4).

Silveira (2015), in studies with black oats at the density of 220 plants $\mathrm{m}^{2}$ in successive cuts at the vegetative stage found the same trend of the present study, where crude protein levels decreased from $27.65 \%$ in the first cut to $21.75 \%$ in the second cut. For the neutral detergent fiber content, the author reported the opposite results, with $50.87 \%$ in the first cut and $56.83 \%$ in the second cut, due to the low rainfall indices (Figure 1) after the first cut. According to Tiritan et al. (2013), in situations of water deficit, the plant increases the proportion of fiber carbohydrates and consequently decreases the cytoplasmic components of the cells, also due to the decrease in the leaf/stem ratio (Table 3).

Carletto et al. (2017) evaluated wheat in vegetative phase and in successive cuts and found crude protein values of $20.43 \%$ in the first cut, and $16.73 \%$ in the second cut.

With the increasing number of cuts, the protein content tended to decrease, due to the need for nutrient consumption for regrowth, a high amount of nitrogen is required, which impacts on the protein content (Buxton and O'kiley, 2003), a fact that may explain the reduction in crude protein contents found in the present study.

The increase in acid detergent fiber can be attributed to the stage of development of the crops, since an older plant has a greater cell wall thickening and lignification (Carvalho and Pires, 2008).

Table 6 lists the contents of hemicellulose, cellulose, lignin, total digestible nutrients and in situ dry matter digestibility of black oat forage grown in two stands of plants subjected to successive cuts. The plant population significantly influenced $(\mathrm{P}<0.05)$ the contents of hemicellulose and total digestible nutrients of the forage. Black oat when grown with a 175 plants $\mathrm{m}^{2}$ stand was higher than with 350 plants $\mathrm{m}^{2}$ in hemicellulose $(16.31 \%$ vs. $13.42 \%)$, in the concentration of total digestible nutrients $(67.46 \%$ vs $65.56 \%$ ), and in situ digestibility of the whole plant $(81.31 \%$ vs $77.68 \%$, respectively). This can be explained by the high correlation between acid detergent fiber and dry matter digestibility (Van soest, 1994).

Horst et al. (2017) evaluated cultivars of different winter cereals for pre-dried production, using 265 plants $\mathrm{m}^{2}$, for black oat cv. EMB 139, and found mean values of $60.9 \%, 23.7 \%, 42.3 \%$ and $5.7 \%$ for in situ dry matter digestibility and hemicellulose, cellulose and lignin contents, respectively.

In the comparison between the cuts, regardless of the plant population (Table 6), hemicellulose, lignin, total digestible nutrients and in situ digestibility of the whole plant decreased from the first to the second cut $(\mathrm{P}<0.05)$, from 21.07 to $8.65 \%$ in hemicellulose, from $6.82 \%$ to $4.72 \%$ in lignin, from $67.33 \%$ to $65.70 \%$ in total digestible nutrient and from $85.67 \%$ to $73.31 \%$ in in situ digestibility of the whole plant. The only parameter evaluated that increased in the second cut was the cellulose, from $22.50 \%$ in the first cut to $26.92 \%$ in the second cut.

As observed in the present study, the increase in the percentages of senescent material (Table 3) generates an increase of low digestible materials, such as cellulose or indigestibles, reducing the nutritional value and digestibility potential of the forage (Van soest, 1994). This assertion explains the fact that the second cut presented lower in situ dry matter digestibility.

According to Van Soest (1994), the advancing plant age exerts an effect on the fraction of the cell wall. First, the carbohydrate proportion of the cell wall increases, but simultaneously, the characteristics of the chemical composition and digestion are also altered. 
Table 6. Contents of hemicellulose, cellulose, lignin, total digestible nutrients and in situ dry matter digestibility coefficient of black oats grown with two population stands associated with two cutting seasons

\begin{tabular}{|c|c|c|c|}
\hline \multirow{2}{*}{$\begin{array}{l}\text { Stand of plants } \\
\mathrm{m}^{2}\end{array}$} & \multicolumn{2}{|c|}{ Cuts } & \multirow[t]{2}{*}{ Mean } \\
\hline & $1 \mathrm{st}$ & 2nd & \\
\hline & \multicolumn{3}{|c|}{ Hemicellulose, \% DM } \\
\hline 175 & 24.05 & 8.56 & $16.31 \mathrm{~A}$ \\
\hline 350 & 18.09 & 8.74 & $13.42 \mathrm{~B}$ \\
\hline Mean & $21.07 \mathrm{a}$ & $8.65 \mathrm{~b}$ & \\
\hline \multicolumn{4}{|c|}{ Cellulose, \% DM } \\
\hline 175 & 20.24 & 27.63 & $23.94 \mathrm{~A}$ \\
\hline 350 & 24.75 & 26.21 & $25.48 \mathrm{~A}$ \\
\hline Mean & $22.50 \mathrm{~b}$ & $26.92 \mathrm{a}$ & \\
\hline \multicolumn{4}{|c|}{ Lignin, \% DM } \\
\hline 175 & 6.05 & 4.31 & $5.18 \mathrm{~A}$ \\
\hline 350 & 7.58 & 5.12 & $6.35 \mathrm{~A}$ \\
\hline Mean & $6.82 \mathrm{a}$ & $4.72 \mathrm{~b}$ & \\
\hline \multicolumn{4}{|c|}{ Total digestible nutrients, $\%$} \\
\hline 175 & 69.44 & 65.48 & $67.46 \mathrm{~A}$ \\
\hline 350 & 65.21 & 65.91 & $65.56 \mathrm{~B}$ \\
\hline Mean & $67.33 \mathrm{a}$ & $65.70 \mathrm{~b}$ & \\
\hline \multicolumn{4}{|c|}{ In situ digestibility of the whole plant, \% } \\
\hline 175 & 88.75 & 73.87 & $81.31 \mathrm{~A}$ \\
\hline 350 & 82.60 & 72.75 & $77.68 \mathrm{~B}$ \\
\hline Mean & $85.67 \mathrm{a}$ & $73.31 \mathrm{~b}$ & \\
\hline
\end{tabular}

Mean values followed by different uppercase letters in the same column in the black aot comparison between plant stands or followed by different lowercase letters in the same row in the comparison between cutting seasons are significantly different from each other by the F-test at $5 \%$ probability.

*First cut (1st); Second cut (2nd)

*Dry mater (DM)

In relation to the rumen disappearance rate of the forage (Figure 2), it is possible to observe that the first cut in both stands of plants resulted in a higher concentration of soluble nutrients, representing the intercept of the curve, with $46.60 \%$ and $39.04 \%$ for 175 and 350 plants $\mathrm{m}^{2}$, respectively. The lower concentration of total soluble nutrients in the second cut in both stands may be related to the higher proportion of stems in this cut. Horst et al. (2017) in studies with black oats for the production of pre-dried with 265 plants $\mathrm{m}^{2}$ found mean values of total soluble nutrients of $28.12 \%$, which is lower than that of the present study.

In general, the ruminal disappearance rates of dry matter of the black oat plant subjected to different population densities obtained in the present study can be classified as good quality. According to Leng (1990), forage classified as low quality are those with values below $55 \%$.

Velásquez et al. (2010) verified a higher digestibility coefficient in forages that present lower concentrations of neutral detergent fiber and acid detergent fiber and higher concentrations of crude protein and non-fiber carbohydrates, evidencing the relationship between these nutrients as well as in the present study. Still the same authors infer that the values of neutral detergent fiber, acid detergent fiber and lignin presented negative correlation with digestibility. The decline in forage digestibility with advancing plant age progresses is reported in practically all studies of this nature. 


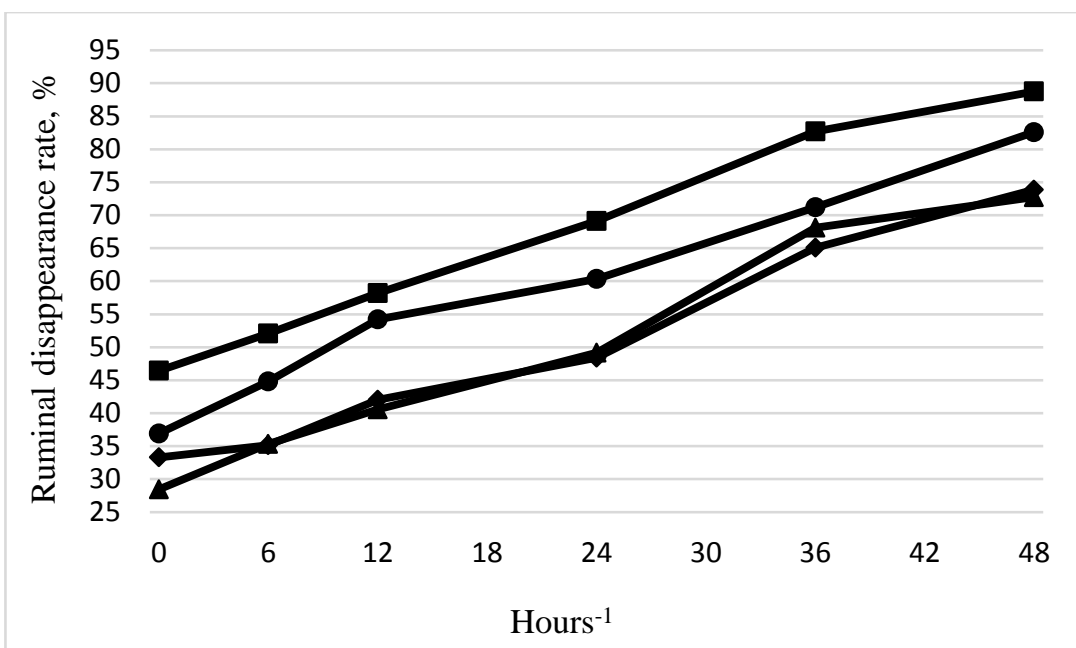

-RDDM 175 plants $\mathrm{m}^{2} 1$ st cut: $46.6057+0.9260 \mathrm{H}\left(\mathrm{CV}: 7.23 \% ; \mathrm{R}^{2}: 0.9189 ; \mathrm{P}=0.0001\right)$

- RDDM 175 plants $\mathrm{m}^{2}$ 2nd cut: $30.6851+0.8958 \mathrm{H}\left(\mathrm{CV}: 8.52 \% ; \mathrm{R}^{2}: 0.9315 ; \mathrm{P}=0.0001\right)$

- RDDM 350 plants $\mathrm{m}^{2}$ 1st cut: $39.0401+0.9123 \mathrm{H}\left(\mathrm{CV}: 7.65 \% ; \mathrm{R}^{2}: 0.9268 ; \mathrm{P}=0.0001\right)$

$\Delta$ RDDM 350 plants $\mathrm{m}^{2}$ 2nd cut: $28.5096+0.8707 \mathrm{H}\left(\mathrm{CV}: 7.72 \% \mathrm{R}^{2}: 0.9522 ; \mathrm{P}=0.0001\right)$

*First cut (1st); Second cut (2nd)

*Ruminal disappearance of dry matter (RDDM)

* H represents hours of incubation, ranging from 0 to 48 hours.

Figure 2. Ruminal disappearance rate of dry matter of forage of black oat grown with two population stands associated with two cutting seasons.

\section{CONCLUSION}

It is recommended that 175 plants $\mathrm{m}^{2}$ for black oat cv. Embrapa 139 be used for increasing the number of tillers $\mathrm{m}^{2-1}$ and tillers plant ${ }^{-1}$, in addition to improving the in situ digestibility of dry matter of the whole plant, without causing reduction of dry biomass production per unit area. Successive cuts in black oat crops determine variations in dry biomass production and forage quality. In the first cut, there is lower production of dry biomass, but with superior nutritional quality of the forage in relation to the second cut.

\section{REFERENCES}

ALMEIDA, M.L.; MUNDSTOCK, C.M. O afilhamento da aveia afetado pela qualidade da luz em plantas sob competição. Ciênc. Rural, v.31, n.3, p. 393-400, 2001.

ALVES, A.C.; ALMEIDA, M.L.; LIN, S.S. et al. Emissão do afilho do coleóptilo em genótipos de aveia e em diferentes condições de estresses e manejo. Cienc. Rural., v.34, p.385-391, 2004.
ARGENTA, G.; SILVA, P.R.F.; SANGOI, L. Arranjo de plantas em milho: Análise do estadoda-arte. Ciênc. Rural, v.31, n.6, p.1075-1084, 2001.

BOLSEN, K.K.; ASHBELL, G.; WEINBERG, Z.G. Silage fermentation and silage additivesreview. J. Anim. Sci., v.9, p.483-494, 1996.

BUXTON, D.R.; O'KILEY, P. Preharvest plant factors affecting ensiling. In: BUXTON, D.R.; MUCK, R.E.; HARRISON, J.H. (Eds.). Silage science and technology. Madison: [s.n.], 2003. p.199-250.

CARLETTO, R.; NEUMANN, M.; FIGUEIRA, D.N. et al. Production and nutritional value of the wheat silage managed with different cutting systems. Semin. Ciênc. Agrár., v.38, p.335-342, 2017.

CARVALHO, G.G.P.; PIRES, A.J.V. Organização dos tecidos de plantas forrageiras e suas implicações para os ruminantes. Arch. Zootec., v.57, p.13-28, 2008. 
FLARESSO, J.A.; GROSS, C.D.; ALMEIDA, E.X. Época e densidade de semeadura de aveia preta (Avena strigosa Schreb.) e azevém (Lolium multiflorum Lam.) no Alto Vale do Itajaí, Santa Catarina. Rev. Bras. Zootec., v.30, p.1969-1974, 2001.

HORST, E.H.; NEUMANN, M.; SANTOS, J.C. et al. Fiber composition and degradability of forage and pre-dried silage of winter cereals harvested in the pre-flowering stage. Semin. Ciênc. Agrár., v.38, p.2041-2049, 2017.

KREMES, D.I.M.; MAROLLI, A.; ROMITTI, M.V. Relação folha/colmo e percentual de folha nos genótipos de aveia direcionados a produção de forragem. 33 REUNIÃO BRASILEIRA DE PESQUISA DE AVEIA, 33., 2013, Pelotas. Anais... Pelotas: [s.n.], 2013.

LENG, R.A. Factors affecting the utilization of "poor-quality" forages by ruminants particularly under tropical conditions. Nutr. Res. Rev., v.3, p.277-303, 1990.

MANUAL de adubação e calagem para o estado do Paraná. Curitiba: SBCS/NEPAR, 2017. 482p.

MARTINS, J.B.; DEBIASI, H.; MISSIO, E.L. Influência da densidade e velocidade de semeadura no crescimento da aveia preta (Avena strigosa Schreb.), em semeadura direta. Pesqui. Agropecu. Bras., v.14, p.33-40, 2008.

MEINERZ, G.R.; OLIVO, C.J.; VIÉGAS, J. et al. Silagem de cereais de inverno submetidos ao manejo de duplo propósito. Rev. Bras. Zootec., v.40, p.2097-2104, 2011.

MUNDSTOCK, C.M. Manejo para duplo propósito. In: _. Planejamento e manejo integrado da lavoura de trigo. Porto Alegre, 1999. p.207-210.

NOCEK, J.E. In situ and other methods to estimate ruminal protein and energy digestibility. A review. J. Anim. Sci., v.71, p.2051-206, 1988.

OFFICIAL methods of analysis. 16.ed. Arlington: AOAC, 1995. v.2, 474p.
ORTERRO, B.A.; SOUZA, F.G.A.; ORTEGAS, F.G. et al. Caracteristicas produtivas e bromatologicas da aveia preta (Avena strigosa) cultivadas em diferentes densidades de semeaduras. Acta Sci., v.8, p.15-26, 2013.

PEDROSO, A.F.; NOIMAN, D.F.; BERTEGGA, G.T.A. et al. Valor nutricional da aveia preta e do azevém submetidos a cortes simulando pastejo cultivados em diferentes doses de nitrogênio. Rev. Acta Iguazu, v.5, p.25-39, 2010.

POTT, C.A.; MÜLLER, M.M.L.; BERTELLI, P.B. Adubação verde como alternativa agroecológica para recuperação da fertilidade do solo. Rev. Amb., v.3, p.51-63, 2007.

ROSSETO, C.A.V.; NAKAGAWA, J. Época de colheita e desenvolvimento vegetativo de aveia preta, Sci. Agric., v.58, p.731-736, 2001.

SILVA, D.J.; QUEIROZ, A.C. Análise de alimentos, métodos químicos e biológicos. 3.reimp. Viçosa: Universidade Federal de Viçosa, 2009, 235p.

SILVEIRA, A.P. Valor nutritivo de forrageiras de inverno e produção de silagem pré-secada. 2015. 69f. Dissertação (Mestrado em Zootecnia) - Universidade Tecnológica Federal Do Paraná, Dois Vizinhos, PR.

TIRITAN, C.S.; SANTOS, D.H.; MINUTTI, C.R. et al. Bromatological composition of sorghum, millet plant and midget guandu at different cut times in intercropping and monoculture. Acta Sci. Agron., v.35, p.183-190, 2013.

VAN SOEST, P.J. Nutritional ecology of the ruminant. Ithaca: Comstock Publishing, 1994. $476 \mathrm{p}$.

VELÁSQUEZ P.A.T.; BERCHIELLI, T.T.; REIS, R.A. et al. Composição química, fracionamento de carboidratos e proteínas e digestibilidade in vitro de forrageiras tropicais em diferentes idades de corte. Rev. Bras. Zootec., v.39, p.1206-1213, 2010. 